Studia nad Autorytaryzmem i Totalitaryzmem 43, nr 1

Wrocław 2021

https://doi.org/10.19195/2300-7249.43.1.3

MARCIN REBES

ORCID: 0000-0002-1318-1459

Uniwersytet Jagielloński

marcin.rebes@uj.edu.pl

\title{
Nacjonalizm a uniwersalne wartości. Spór o tożsamość z perspektywy filozofii dialogu
}

\author{
Słowa kluczowe: nacjonalizm, filozofia dialogu, Ja, Inny. \\ NATIONALISM AND UNIVERSAL VALUES. THE DISPUTE OVER IDENTITY \\ THROUGH THE PRISM OF THE PHILOSOPHY OF DIALOGUE
}

\begin{abstract}
:
In this chapter I deal with the problem of contemporary nationalism through the prism of the philosophy of dialogue and the question about the identity of the individual and society.

The chapter consists of three parts. Firstly, I conceptualise the notions of nationalism and nation states. Secondly, I present the assumptions of the philosophy of dialogue concerning the problem of identity and the source relationship in philosophy. Thirdly and lastly, I analyse how nationalism is juxtaposed with the universal values as set against the background of the philosophy of dialogue.

Here I do not focus on presenting the definition or assessment of nationalism. I offer instead an insight on some elements that appear particularly strong in the initial phase of the transformation of nationalism in nation-states, which lead to various kinds of dangerous phenomena, and present the problem of nationalism through the prism of national socialism. The phenomenon of nationalism, for which the uniqueness of a nation is one of the most characteristic features, may pose a serious problem not only in international or social relations, but also concerns individuals. The philosophy of dialogue is involved in ethical relations between individuals, but its scope also extends to social and even political issues. Representatives of the philosophy of dialogue noticed the problem of culture grounded in the question of the subject before it led to the drama of the citizens of Europe and, consequently, of the whole world. Therefore, the article juxtaposes nationalism with the postulates of the philosophy of dialogue, which shows identity through the prism of a relationship to another human being.

I consider this problem on the basis of philosophical anthropology. For this purpose, a phenomenological reflection was used, which consists in describing the phenomenon and trying to understand it through the prism of "I". The reason why the philosophy of Hegel, Schopenhauer, and
\end{abstract}


Nietzsche inspires, on the one hand, National Socialism, and on the other, the philosophy of dialogue, is shown. This particular task is to help understand today's problems of nation-states seeking their own identity. The common denominator of these two separate phenomena is the problem of identity.

The problem of symmetry and asymmetry of relations or the problem of violence and being for the other in the concept of the national idea and the philosophy of dialogue is presented. They can be seen through the prism of the question of identity. On the one hand, nationalism is based on universalism, and on the other, it seeks uniqueness, a unique place for its nation. It is clearly in contradiction to universal values which are the same for all. The dispute over identity from the perspective of the philosophy of dialogue touches upon an important issue, which is the importance of the Other for identity. The philosophies of Kant, Hegel, or Nietzsche, when misunderstood, may lead to the conclusion that they are the precursors of nationalism, including National Socialism. However, this is a great misconception. The philosophy of dialogue critically evaluates these thinkers, but they give it a reason to reflect on the essence, on the root question of philosophy.

The philosophy of dialogue teaches that individual experience can be universal, without excluding others. This helps to see the necessary balance between the identity of the individual and the national identity that need each other. National identity is a very important element of human nature, but it must be based on symmetry in interpersonal relations, which can guarantee peace in Europe and the world.

Keywords: nationalism, philosophy of dialogue, I, Other.

Filozofia przez wieki odciskała swoje piętno na różnych dziedzinach życia. Filozofowie próbowali zrozumieć zjawiska, które zachodziły w kulturze i w społeczeństwie. Poprzez swoje analizy również wpływali na rzeczywistość. Myślenie i otaczający nas świat są ze sobą ściśle powiązane. Jednym z takich przykładów jest filozofia dialogu, która odegrała w XX wieku ważną rolę, zmieniając spojrzenie nie tylko na metafizykę, ale także na relacje międzyludzkie.

Trudno jednoznacznie wskazać, kto jest twórcą tego nurtu filozoficznego, ponieważ w podobnym czasie pojawiły się różne dzieła, które koncentrowały się na relacjach międzyludzkich. Powstawały one na gruncie judaizmu i chrześcijaństwa. Twórcy filozofii dialogu dostrzegli, że potrzebna jest nowa podstawa dla europejskiego myślenia. Widzieli bowiem zagrożenie wynikające z redukcji świata do podmiotu i zauważyli w tym niebezpieczeństwo zarówno dla jednostki, jak i dla społeczeństwa czy narodu.

Trudno sobie wyobrazić Europę bez państw narodowych. Nasza tożsamość wiąże nas z określoną kulturą, społecznością i państwem. Jednak obok identyfikacji z konkretnym narodem i przynależności do grup lokalnych pojawia się inna tożsamość, to jest określanie się jako część kultury europejskiej. Tak więc historia Europy dzieli, ale i łączy. Filozofia dialogu koncentruje się na spotkaniu człowieka z człowiekiem i dostrzega w nim źródłowe doświadczenie ich własnej tożsamości.

Nie tylko ze względu na swoje pochodzenie, ale przede wszystkim z racji poglądów ten prąd myślowy nie przystawał do czasów rodzących się nacjonalizmów 
czy w końcu dyktatury narodowego socjalizmu. Jednak zarówno w przypadku filozofii dialogu, jak i nacjonalizmów kluczowym problemem jest tożsamość.

W niniejszym artykule chcę udowodnić tezę, że filozofia dialogu ze względu na swoje podstawy — oparte na relacji, która niezależnie od tego, czy jest symetryczna, czy asymetryczna, zwraca się ku innemu, ku człowiekowi, i dzięki niej dopiero możemy odnaleźć własną tożsamość — stanowi w pewnym stopniu wskaźnik i stabilizator ładu społecznego i międzyn a r o d ow e g o. Fundamentem tej filozofii jest bowiem tożsamość oparta na wartościach, które, mimo że są partykularne, mają uniwersalny wymiar. Podstawą dla dobrze rozumianego nacjonalizmu, kształtującego państwa narodowe, powinno być doświadczenie wspólnych, uniwersalnych wartości, które stają się bazą dla tożsamości narodowej. Dlatego w tym artykule nie rozważam nacjonalizmu przez pryzmat doktryny i idei politycznych, lecz pewnych jego cech, które dotykają ważnego problemu, jakim jest potrzeba tożsamości.

Nie chciałbym sprowadzać nacjonalizmu do jednej definicji ani dokonywać oceny całego zjawiska, pragnę jedynie skoncentrować się na niektórych elementach, szczególnie mocno widocznych w początkowej fazie przekształcania się nacjonalizmu w państwach narodowych, które prowadzą do różnego rodzaju niebezpiecznych zjawisk, oraz przedstawić problem tego nurtu politycznego w odniesieniu do narodowego socjalizmu. Nie chodzi mi o to, aby fenomen nacjonalizmu sprowadzać do jednej jego, skrajnej, postaci, co byłoby dużym uproszczeniem, ale o to, by przedstawić go z perspektywy przedstawicieli filozofii dialogu, którzy wcześniej odnosili się do niego, ostrzegali przed nim, a także są jego ofiarami.

Chciałbym też zastanowić się, dlaczego myśl Georga W.F. Hegla, Arthura Schopenhauera, Friedricha Nietzschego inspiruje z jednej strony narodowy socjalizm, z drugiej zaś filozofię dialogu. To szczególne zagadnienie ma pomóc w zrozumieniu dzisiejszych problemów państw narodowych, szukających własnej tożsamości.

Artykuł składa się z trzech rozdziałów. W pierwszym zostanie omówiony problem nacjonalizmu i państw narodowych, w drugim zaś zaprezentuję zagadnienia związane $\mathrm{z}$ filozofią dialogu. $\mathrm{W}$ trzecim natomiast będzie mowa o tożsamości narodowej z perspektywy filozofii dialogu.

\section{Nacjonalizm i państwo narodowe}

Rozważając filozofię dialogu i jej pytanie o tożsamość, trzeba najpierw przybliżyć ideę nacjonalizmu i państw narodowych. Jednak już na tym etapie naszych rozważań napotykamy trudności, ponieważ pojęcie narodu, podobnie jak nacjonalizmu, nie jest jednorodne. Można powiedzieć, że przechodziło ono różnego rodzaju zawirowania i było definiowane przez rozmaite, często nieprzystające do 
siebie, zjawiska. Państwa narodowe w poszczególnych krajach powstawały w różnych okresach historycznych, ponadto procesy te miały odmienne podłoża.

Pierwsze państwa narodowe rodziły się w przededniu wybuchu rewolucji francuskiej. Wzrosła wtedy nie tylko świadomość na rodowa, lecz także św ia domość je d no st ki, która szuka swojej własnej tożsamości. W tym czasie również powstała myśl Hegla, Johanna G. Fichtego, Friedricha von Schellinga i innych filozofów, którzy podejmowali problem tożsamości. Ujmowali ją w odniesieniu do dziejowości, celów, jakie poszczególne kultury czy narody powinny zrealizować, aby ludzkość dotarła do „ducha absolutnego”. Pojawiła się „świadomość” „Ja", które poznając siebie i otaczający go świat, przyswaja sobie to, co do niego wcześniej nie należało. Dzięki Fichtemu rozwijał się nie tylko problem tożsamości jednostki, która uczy się świata, ale również identyfikacji narodu przez pryzmat pojęcia Volk, czyli ludu. Hegel natomiast przyczynił się do rozwinięcia idei predestynacji, analizowanej przez niego razem z problemem wolności w $\mathrm{Fe}$ nomenologii ducha ${ }^{1}$. W tym kontekście ukazał on walkę na śmierć i życie, w której ścierają się światy panów i niewolników. Pan to ten, który nie ugina się przed śmiercią, niewolnik natomiast odwrotnie. Ostatecznie jednak pan uzależnia się od niewolnika, nie może bez niego żyć, niewolnik natomiast żyć bez pana może ${ }^{2}$.

Hegel operował kategorią ducha, co można różnie rozumieć. Nie oznacza to jednak, że w procesie myślenia odrzuca to, co inne, lecz że przyswaja je. Tożsamość to nie tylko „Ja”, ale również to, co staje się „mną”. Przedstawiciele idealizmu niemieckiego inspirowali twórców państw narodowych, ale także filozofię i kulturę europejską, które zwracają się ku jednostce. Dlatego perspektywa zestawienia problematyki państw narodowych i nacjonalizmu z filozofią dialogu wydaje się jak najbardziej uzasadniona. Kluczowy jest tutaj problem tożsamości i innego oraz ich rola w kształtowaniu się świadomości samego siebie. Przed pojawieniem się nurtu określanego idealizmem niemieckim powstała także filozofia Immanuela Kanta. Również ona wiąże ze sobą te odmienne od siebie myśli. Kant zajmował się problemem wolności i tym, w jaki sposób człowiek poznaje siebie i świat. Ten prąd myślowy wskazuje $\mathrm{z}$ jednej strony na fakt, że człowiek nie poznaje świata takim, jaki on jest, lecz same zjawiska, to znaczy to, w jaki sposób rzeczy dają się zobaczyć. Następowanie po sobie zjawisk jest wynikiem działania ludzkiego rozumu. $Z$ drugiej strony myśliciel z Królewca zajmował się ideami, które istnieją niezależnie od intelektu. Rozróżnia różne typy wolności, jak spontaniczność czy autonomia ${ }^{3}$. Ta pierwsza przynależy do teorii poznania, dotyczy poznawanego zewnętrznego świata, druga, autonomia, pojawia się na poziomie moralności. Autonomia polega na tym, że człowiek determinuje swoją wolę działania zgodnie z prawem moralnym. Kant pisał też o zasadach współistnienia w społeczeństwie,

1 G.W.F. Hegel, Fenomenologia ducha, przeł. Ś.F. Nowicki, Warszawa 2002, s. 141.

2 Ibidem, s. $136 \mathrm{n}$.

3 I. Kant, Krytyka czystego rozumu, t. 2, przeł. R. Ingarden, Kraków 1957, s. 8 n; oraz I. Kant, Krytyka praktycznego rozumu, przeł. J. Gałecki, Warszawa 2004, s. 85. 
a także o roli organizacji międzynarodowych, które mogą zagwarantować pokój na świecie ${ }^{4}$. Klimat wokół wspomnianych filozofii, a także one same wpływały na rozwój antropologii filozoficznej oraz koncepcji państw narodowych.

Współczesne rozumienie narodu odbiega zdecydowanie od tego, jak go interpretowano w starożytnej Grecji czy za czasów monarchii dziedzicznych. Dziś jest on rozumiany przez pryzmat państw narodowych. U podstaw ich idei leży nacjonalizm. Jak twierdził Ernest Gellner, to nie nacjonalizm pochodzi od narodu, ale właśnie nacjonalizm tworzy naród ${ }^{5}$. Brytyjski badacz rozważał pewną widoczną w myśli nacjonalistycznej zależność, jaką jest powiązanie narodu z państwem i instytucjami, które przejmują od jednostki wiele kompetencji.

Nacjonalizm korzysta z kultury, ale także ze struktur państwowych. Nie jest jednak prawdą, że jest on naturalną cechą człowieka i społeczeństwa - wypacza on kulturę, tworząc własną, wyższą. Gellner bronił także Kanta przed oskarżeniem, że ten był twórcą nacjonalizmu. Proponowana przez Brytyjczyka unifikacja - szukanie jedności - jest wykorzystywana do budowania koncepcji politycznej, gdy tymczasem pruski filozof traktował jedność w odniesieniu do ludzkiego rozumu.

Ciekawym spostrzeżeniem Gellnera była krytyka obecnej we współczesnym nacjonalizmie tendencji do ujednolicania. Tymczasem w wiekach wcześniejszych istniały obok siebie różne grupy etniczne, kultury i języki. Jest to jedna z wielu różnic między rozumieniem narodu i nacjonalizmu w starożytnej Grecji czy Rzymie oraz w średniowieczu a współczesnymi przekonaniami na ten temat.

Do wspomnianych wcześniej filozofów należą także Schopenhauer czy Nietzsche, którzy podkreślali, że natura człowieka nie jest jedynie racjonalna, bo głównym jej elementem jest wola ${ }^{6}$. Nietzsche pisał o woli mocy, sile, która nie jest ani moralna, ani niemoralna ${ }^{7}$. Jeszcze bardziej dobitnie zwrócił uwagę na sens subiektywności, „pluralizmu moralnego”, to znaczy ilu jest ludzi, tyle jest moralności. Niemiecki filozof odrzucał koncepcję wolności na rzecz fatum — przeznaczenia, które nie jest od nas zależne. To, co możemy jedynie zrobić, to je przyjąć. Nietzsche skupiał się na woli mocy, nieustannej walce sił. Oprócz elementów racjonalnych dostrzegał w człowieku wolę, która może kierować się różnymi pobudkami. Ukazywał on także sens prawdy, która kultywowana jest tylko wówczas, gdy służy partykularnym korzyściom ${ }^{8}$. To odkrycie natury człowieka, która może kierować się resentymentem, poważnie zaważyło na koncepcji człowieka. Max Scheler starał się odpowiedzieć na zarzuty Nietzschego, koncentrując się na subiektywnym

${ }^{4}$ I. Kant, O wiecznym pokoju. Zarys filozoficzny, przeł. F. Przybylak, Wrocław 1992.

5 E. Gellner, Narody i nacjonalizm, przeł. T. Hołówka, Warszawa 1991, s. 72.

6 A. Schopenhauer, Świat jako wola i przedstawienie, t. 1, przeł. J. Garewicz, Warszawa 1994, s. 33.

${ }^{7}$ F. Nietzsche, Wola mocy, przeł. S. Frycz i K. Drzewiecki, Kraków 2009, s. 209 n.

${ }^{8}$ F. Nietzsche, O prawdzie i ktamstwie w pozamoralnym sensie, [w:] idem, Pisma pozostate 1862-1875, przeł. B. Baran, Kraków 1993, s. 184 n. 
przeżyciu wartości, które jest częścią uniwersalnego świata aksjologii ${ }^{9}$. W tym kontekście pojawiły się problem uczestnictwa w wartościach i nowe spojrzenie na znaczenie solidarności międzyludzkiej (w odróżnieniu od Émile’a Durkheima i jego koncepcji solidarności mechanicznej i organicznej ${ }^{10}$ ).

Nacjonalizm, a także pośrednio państwa narodowe, rozumiane są zazwyczaj, choć nie zawsze, przez pryzmat walki i siły, dialektyki, w której chodzi o dominację. Te różnice między nacjonalizmem inspirowanym filozofią Hegla a jego nietzscheańską odmianą są widoczne także w rozróżnieniu nacjonalizmów historycznego i wolitywnego. Ten drugi staje się szczególnie ważny w epoce industrialnej. Oczywiście wątki wolitywne istniały zdecydowanie wcześniej niż myśl Nietzschego, lecz to on sprawił, że podejmowano je zdecydowanie częściej. Wymienieni filozofowie są wyrazicielami pewnych tendencji, które pojawiały się już wcześniej.

Cechą nacjonalizmu jest to, że walka nie dotyczy samej polityki, ale także innych sfer, takich jak życie społeczne, kulturalne, a także filozofia. Świadczą o tym wyraźnie próby jego zdefiniowania. Nacjonalizm, jak zauważyli wspomniani wcześniej myśliciele, pierwotnie wykorzystuje przemoc jako środek do powiązania tego, co państwowe, społeczne, kulturowe, z ideą $n$ a r o d ow ą. Posiada on różne cechy charakterystyczne, jednak na pierwszy plan wysuwa się nadrzędny wobec jednostki, grup społecznych i społeczności regionalny interes narodu. Nacjonalizm pojawia się nie tylko na poziomie relacji wewnątrz państwa, lecz również w stosunkach międzynarodowych. Interes własnego kraju jest ważniejszy niż cele innych państw. W tym sensie naród uznawany jest za najwyższego suwerena, dla którego najwłásiwszą formą organizacji społecznej jest państwo narodowe. Za podstawę przyjmuje ono wspólne pochodzenie, język oraz kulturę (wspólne historia, oczekiwania i plany). Mniejszości narodowe i etniczne muszą podporządkować się woli suwerena. Czy taki model można utrzymać w państwach wielokulturowych?

Nacjonalizm zakłada relację asymetryczną pomiędzy jednostką a państwem narodowym, a także między państwami. To znacząco wpływa na problem koegzystencji państw narodowych. Nacjonalizm, a następnie państwa narodowe, powstawały w różnym okresie w poszczególnych krajach. Ważną cezurę w tym procesie stanowi Wiosna Ludów w roku 1848. Ten ruch rewolucyjny sprzyjał zmianom w świadomości społecznej, ale także tworzeniu narodów, które walczą o dominację. Wytworzyło się wtedy poczucie związku między państwem a jego społeczeństwem i kulturą. Nacjonalizm zniekształca to odczucie, łącząc ze sobą różne rzeczywistości, co odróżnia jego współczesną wersję od tych wcześniejszych, na przykład wywodzącego się ze starożytności umiłowania swojej Patrii.

\footnotetext{
9 M. Scheler, Resentyment a moralność, przeł. J. Garewicz, Warszawa 1997, s. 174 n.

10 É. Durkheim, O podziale pracy społecznej, przeł. K. Wakar, Warszawa 2012, s. 193.
} 
Jedną z kluczowych cech nacjonalizmu jest as ymetryczny charakter relacji między narodami. Głównym problemem staje się walka o dominację, która wyrasta z przekonania o wyjątkowości danego narodu. Pojawia się tu nawiązanie do filozofii idealizmu niemieckiego, która nie tylko ukazuje proces dochodzenia do rozumu absolutnego, ale koncentruje się na zagadnieniu tożsamości. W tym kontekście pojawia się identyfikacja narodu, ale również jednostki. Ten rodzaj transcendencji wskazuje na tożsamość jako ważny element życia człowieka. Filozofia dialogu powstała jako odpowiedź na pytanie o tożsamość. Stawiała ona pytanie o relacje międzyludzkie i ich kryzys, który rozpoczął się od okresu oświecenia, dostrzegła zagrożenia wypływające $\mathrm{z}$ redukcji istniejących wartości uniwersalnych do wartości, które są użyteczne dla społeczeństwa i państwa.

Filozofia dialogu powstała zdecydowanie później niż nacjonalizm, ale zwracała uwagę na niebezpieczeństwo jego powiązania z kulturą, społeczeństwem czy państwem. Jej twórcy będą chcieli przekształcić kulturę opartą na dialektyce w kulturę dialogu ugruntowaną na etycznym doświadczeniu „Innego”.

\section{Filozofia dialogu}

Przedstawiciele tego prądu myślowego, krytykując kulturę europejską, ukazywali jej tendencje do niszczenia różnorodności. Według nich sprowadza ona świat zewnętrzny, Boga, a także innych ludzi, do „ego”, „Ja”. Filozofia dialogu dostrzegała $\mathrm{w}$ tym zjawisku ogromne zagrożenie, widziała je również $\mathrm{w}$ coraz bardziej powszechnym nacjonalizmie. Mimo że Martin Buber, jeden z przedstawicieli tej filozofii, początkowo interesował się ruchem syjonistycznym, postulującym utworzenie państwa żydowskiego, to jednak centralnym zagadnieniem w swoich rozważaniach uczynił doświadczenie religijne, z którego powinna wyrastać wszelka metafizyka ${ }^{11}$. Polityka może korzystać z religijnej idei mesjanizmu, lecz u przedstawicieli filozofii dialogu wyrasta ona z relacji między indywiduami. W omawianym nurcie myślowym kluczowym problemem jest oparcie filozofii na doświadczeniu, czyli na nowych podstawach. Powróćmy zatem do pytania o tożsamość.

\subsection{Inspiracje i powstanie filozofii dialogu — pytanie o tożsamość}

Pytanie o „Ja” i próba znalezienia tożsamości leżą u podstaw filozofii dialogu. Przedstawiciele idealizmu niemieckiego nadawali zagadnieniu tożsamości szczególne znaczenie. Kartezjańskie rozróżnienie na rzeczy myślące i rozciągłe ukazywało ważny element samego procesu kogitacji od rzeczy poznawanych przez zmysły. Idealizm niemiecki, a zatem Hegel, Fichte, Schelling oraz myśl Kanta,

11 J. Doktór, Wstęp, [w:] M. Buber, Ja i Ty. Wybór pism filozoficznych, przeł. J. Doktór, Warszawa 1992, s. 10. 
przedstawiał stosunek ,Ja” do tego, co nim nie jest. Proces poznawczy zmierzał do tego, aby przyswoić sobie to, co nie jest „Ja”. Hegel dostrzegał przyswajanie w horyzoncie wolności.

Filozofia dialogu stanowi próbę odpowiedzi na pytanie o tożsamość jednostki w relacji z innymi. Ten prąd myślowy jak mało która dyscyplina naukowa sygnalizował problem nacjonalizmu, zanim powstał narodowy socjalizm i w Europie wybuchły dwie wielkie wojny. Wskazywała na problem kultury, która wyklucza różnorodność, inność poprzez wchłanianie jej przez świadomość całości, systemu, który neutralizuje różnice. Tego rodzaju poglądy w podobnym czasie kształtowały się u Bubera, Franza Rosenzweiga i Ferdinanda Ebnera. Kolejnymi przedstawicielami tego nurtu, działającymi pół dekady później, byli Eugen Rosenstock-Huessy, Gabriel Marcel czy Eberhard Grisebach ${ }^{12}$. Mimo różnic między przedstawicielami tworzącej się filozofii dialogu wspólną podstawą ich myśli była relacja między ludźmi. Chcieli oni, aby na nowo poddać refleksji dotychczasową metafizykę oraz postawić pytanie o źródłowe doświadczenie.

Podłożem ich przemyśleń było przeżycie religijne, na którym koncentrowali się i które uczynili podstawą filozofii. W ten sposób filozofia musiała porzucić myślenie oparte na relacji podmiot-przedmiot. Świat widziany przez pryzmat podmiotu redukuje go jedynie do jednej sfery. Wszystko, co różne, zostaje odrzucone. Doświadczenie Boga jest doświadczeniem, któremu wymyka się owa jedność. Zbudowana na przeżyciu religijnym filozofia dialogu dostrzegała dysproporcje między adwersarzami, ale ukazywała możliwą jedność, wykraczającą poza przedstawienie w formie podmiot-przedmiot. Nie oznacza to, że nurt ten odrzucał podmiot, lecz że zestawiał go z doświadczeniem spotkania. Rozwijał on refleksję nad kontaktem między ludźmi w trudnych czasach, gdy doświadczenie etyczne jest bardziej postulatem niż zjawiskiem obserwowanym na co dzień.

Rosenzweig pisał swoje dzieła w czasie I wojny światowej. To, co łączyło dialogików, to nie tylko doświadczenia wojenne, ale przede wszystkim walka z fi lozofią subiektywistyczną, która prowadzi do kultury wykluczającej to, co inne. Nurt ten nie był odrzucany przez myśl dialogiczną, która próbowała ją ugruntować na doświadczeniu spotkania. Dopiero poprzez relacje międzyludzkie podmiot uświadamia sobie pełnię swojej istoty, odzyskuje własną tożsamość, którą przedstawiciele idealizmu niemieckiego postrzegali jako problem. W procesie dochodzenia do samoświadomości zamiast „Nie-Ja” pojawia się „,drugi”, „Inny”. Dialogicy dostrzegają bowiem źródłowe doświadczenie w „zetknięciu się" człowieka z innym człowiekiem czy człowieka z Bogiem. Przy czym w tym przeżyciu nikt nie traci swojej tożsamości, a wszyscy zyskują wspólną przestrzeń.

Dla przedstawicieli filozofii dialogu źródłowym doświadczeniem jest spotkanie drugiego człowieka czy bliskość Boga. Rosenzweig odwołuje się często do Hegla, czyni to także poprzez dzieła Hermanna Cohena, między innymi Religię rozumu

12 M. Buber, op. cit. 
ze źródet judaizmu ${ }^{13}$. Ten, będący początkowo neokantystą krytycznie oceniającym Hegla, odróżniał świadomość (Bewusstsein) od rozumu (Vernunft) ${ }^{14}$. W tej pierwszej ukazywał dziejowość, o której pisał Hegel. Różne formy ludzkiej świadomości mają udział w ,życiu” rozumu. Jednak ten ma swoją podstawę w religii, mimo że w nim ukazuje się świadomość dziejowości. Cohen był przekonany, że rozum wykracza poza ramy tego, co narodowe. Wskazywał bowiem na uniwersalny charakter religii, ale dostrzegał również funkcję, jaką ma pełnić każdy „naród" dla ludzkości. Z czasem niemiecki filozof żydowskiego pochodzenia oddalił się od myśli neokantowskiej i zwrócił się ku pojęciu relacji, które rozwiną dialogicy. Zwracał on uwagę na problem relacji „Ty”, „On” i „To”. Szczególnie istotna jest relacja $\mathrm{z}$ „To”, ponieważ w niej drugi podmiot traktowany jest na równi z rzeczami, co stanowi niezrozumienie istoty „Ty”. Odkrył on problem etyczny „Ty”, z doświadczeniem religijnym, w którym odnalazł swoje własne ,Ja”, jako podstawą. Z kolei Rosenzweig w swoim dziele Gwiazda Zbawienia $(1921)^{16}$ dostrzegł w twarzy człowieka tajemnicę, w której znajduje się ślad Boga. Opisywał on dwa trójkąty — jeden pasywny, drugi aktywny - które tworzą gwiazdę Zbawienia. Podstawą tej filozofii jest relacja człowieka z Bogiem przez pryzmat „Innego”. Filozofia Rosenzweiga w przyszłości odcisnęła mocne piętno na myśli Bubera.

Ten w książce Ja i Ty z 1922 roku opisywał relację najbardziej źródłową, o któ-

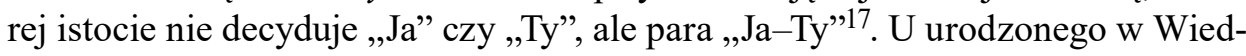
niu filozofia relacja ta miała charakter dialogiczny, symetryczny. Pojawia się ona w spotkaniu, które wydarza się między nami, to znaczy między „Ja” i „Ty”. Buber odnosił się nie tylko do filozofii ukazującej stosunek ,Ja-Ty”, odwoływał się bowiem również do relacji „My”, kwestii społecznych i politycznych. Podstawą tych relacji będzie odnowa duchowa.

Ten przedstawiciel filozofii dialogu, nawiązując do wizji Hegla i jego Fenomenologii ducha, krytykował problem polityki, której podstawą jest d om in acja. Filozofia dialogu, w przeważającej mierze inspirowana judaizmem, ale również chrześcijaństwem, postrzega dziejowość w kontekście religii, która nakazuje odrzucenie antropologizacji, niwelacji Boga do człowieka. Jeszcze przed powstaniem idei powiązania relacji „Ja” i „Ty” Buber w 1901 roku wziął udział w V Kongresie Syjonistycznym, w czasie którego Theodor Herzl domagał się powstania państwa Izrael. Omawiany przez nas myśliciel wówczas nie postulował założenia tego rodzaju tworu na terenie Palestyny, lecz oczekiwał przede wszystkim odnowy du-

13 H. Cohen, Religion der Vernunft aus den Quellen des Judentums. Eine judischen Religionsphilosophie, Wiesbaden 2008, https://pdfs.semanticscholar.org/4dec/0268d80728a36005bc73c 10f5db1c2e00a0e.pdf (dostęp: 29.08.2020).

14 Ibidem, s. 36.

15 B. Baran, Przedmowa, [w:] Filozofia dialogu, oprac. B. Baran, Kraków 1991, s. 11.

16 F. Rosenzweig, Gwiazda Zbawienia, przeł. T. Gadacz, Kraków 1998.

17 M. Buber, op. cit., s. 39 n. 
chowej. Ta różnica poglądów między Herzlem a Buberem wskazywała na poważne rozbieżności między nimi, ale także na konstrukcję narodu opartą na szczególnego rodzaju relacjach. Już wówczas myśliciel dążył do utworzenia w narodzie nowej kultury $^{18}$. Dla niego nacjonalizm oznaczał odkrycie człowieczeństwa i, co istotne, odzwierciadlał podstawowe odniesienie jednostek do siebie ${ }^{19}$. W roku 1904 Buber odkrył chasydyzm. W odniesieniu do tego nurtu religijnego pobożność jawiła się jako dialogiczna więź, szczególnego rodzaju relacja Boga i człowieka. Filozof skłaniał się ku jednostce, pozostawiając na drugim planie prawo. Biorąc pod uwagę tę opinię, koncentrował się on nie tyle na państwie czy narodzie, który wiąże ze sobą struktury państwowe jako instytucje, społeczeństwo, historię, kulturę i religię na gruncie narodowym, lecz na fundamencie odnowy religijnej. Buber był przeciwnikiem państwa jednonarodowego.

Na wzmiankę zasługuje jeszcze jedno dzieło jego autorstwa - mowa o Problemie człowiek $a^{20}$, bo to właśnie w nim pojawia się krytyka filozofii Kanta, Nietzschego i Martina Heideggera, a także problem konieczności pewnej symetrii między kulturą niską (społeczeństwem) a kulturą wysoką (państwem). W ten sposób urodzony w Wiedniu myśliciel dokonał negatywnej oceny państwa narodowego, które ma na celu ścisłe powiązanie państwa jako instytucji ze sferą społeczną. Buber mimo swoich silnych przekonań politycznych był wierny filozoficznemu rozumowaniu, którego podstawą jest doświadczenie etyczne. Przenosił myślenie religijne na grunt etyczny, który dostrzegał w spotkaniu, relacji „Ja-Ty”.

W niej ważną rolę odgrywa mowa. Problem ten rozwinie Ferdin and Ebner, znany ze swojego najsłynniejszego dzieła, Stowa i realności duchowych z 1921 roku, a także książki Słowo i miłość (1931) ${ }^{21}$. Ebner dostrzegł znaczenie mowy szczególnie w czasie I wojny światowej, w której odkrył pustkę nacjonalizmu, ale także próżnię religijną. Sięgnął on wówczas po twórczość Sørena Kierkegaarda oraz do myśli Wilhelma von Humboldta i jego filozofii mowy ${ }^{22}$, której znaczącą rolę dostrzegał $\mathrm{w}$ dialogu ${ }^{23}$. Najbardziej źródłową relacją w filozofii jest dla niego relacja człowiek-Bóg. W niej nie można sprowadzić Boga do siebie, to znaczy konieczne jest wejście w nią przy zachowaniu Bożej autonomii. Prawda odsłania się w mowie, która nie niszczy odrębności osób - jest moja, lecz przychodzi z przestrzeni, która znajduje się na zewnątrz mnie. To odniesienie mowy do źródła Ebner nazywał pneuma. Mowa może być różnie rozumiana, o czym bę-

18 J. Doktór, op. cit., s. 11.

19 M. Buber, Autobiographische Fragmente, [w:] Philosophie of Martin Buber, Evanston 1963, s. 11, cyt. za: J. Doktór, op. cit., s. 12.

20 M. Buber, Problem czlowieka, przeł. R. Reszke, Warszawa 1993, s. 12 n.

${ }^{21}$ F. Ebner, Fragmenty pneumonologiczne, [w:] Filozofia dialogu, oprac. B. Baran, Kraków 1991.

22 B. Casper, Wstęp, [w:] F. Ebner, Stowo i realności duchowe. Fragmenty pneumatologiczne, przeł. K. Skorulski, Warszawa 2006, s. VIII.

${ }^{23}$ Filozofia dialogu, s. 21. 
dzie pisał później Emmanuel Levinas w książce Inaczej niż być lub ponad istotą ${ }^{24}$. Dla Ebnera istotne było to, że dzięki mowie wychodzimy poza siebie, poza sferę podmiotu. Ma ona według niego charakter etyczny.

Z perspektywy etyki i problemu tożsamości ważna jest relacja „Ja”-,To”, czyli uprzedmiotowienie drugiego człowieka. Ebner przestrzega przed sprowadzeniem źródłowej relacji do stosunku „Ja”-,,To”, do czego przekonywał wspomniany wcześniej Cohen. Wówczas trzecia osoba sprowadzona jest do „ego”, które niszczy inność. Ten mechanizm, widoczny w działaniu narodowego socjalizmu w Niemczech, sprawiał, że ludzie stanowili jedynie trybik w sprawnej maszynie. Nie mieli etycznych zasad, lecz jedynie cel, który uświęca środki.

Zapoczątkowaną przez Ebnera analizę zagadnienia mowy kontynuował Eu gen Rosenstock-Huessy w Duszoznawstwie stosowanym z 1924 roku. Stwierdził on, że filozofia musi zająć się „systemem słownym”, czyli gramatyką. Tak jak logika i teoria poznania znajdują się u podstaw nauk humanistycznych i przyrodniczych, tak gramatyka pozwala dotrzeć do głębi ludzkiej duszy i mowy ${ }^{25}$. W tym sensie człowiek znajduje się w przestrzeni „Ja” i „Nie-Ja”. Rosenstock-Huessy zwracał uwagę na problem pierwszej osoby gramatycznej, do której będą się odwoływać także przedstawiciele fenomenologii, między innymi Edmund Husserl.

Wyjaśnienie problemu pierwszej osoby gramatycznej, ,Ja”, jest jednak niewystarczające. Dlatego Gabriel Marcel, autor takich prac jak Dziennik metafizyczny $(1927)^{26}$ czy Być i mieć (1935) ${ }^{27}$, skoncentrował się na dialogu między podmiotami. Rozważał on ten problem między innymi w pierwszym ze wspomnianych dzieł $^{28}$. Francuski myśliciel, przedstawiając stosunki między Bogiem a człowiekiem, doszukiwał się relacji, w której brak wszelkiego finalizmu, perspektywy dziejowej, zmierzania do jakiegoś końca. Same warunki, które zachodzą, byłyby jedynie dynamiczną sytuacją, wykraczającą poza dzieje jednostki. Dlatego Marcel wprowadził kategorię spotkania ${ }^{29}$. Zauważył on w Być i mieć, że jedynie to, co posiadam, może być przedmiotem osądu, nie może nim być natomiast nie samo istnienie. Tym, co wiąże istnienie i posiadanie, są miłość i zaufanie, którymi to pojęciami posługiwał się Francuz. Obydwa te określenia wykraczały poza dotychczasowe zainteresowania filozofii.

Na problem istnienia „Innych” i „mojej” hegemonii, chęci panowania, zwraca uwagę kolejny dialogik, Eberhard Grisebach. Napisał on książkę zaty tułowaną

24 E. Levinas, Inaczej niż być lub ponad istota, przeł. P. Mrówczyński, Warszawa 2000.

25 Por. E. Rosenstock-Huessy, Angewandte Seelenkunde. Eine Programmatische Übersetzung, Darmstadt 1924, s. 24 n.; idem, Gramatyka duszy, przeł. T. Gadacz, [w:] Filozofia dialogu, s. 98.

26 G. Marcel, Dziennik metafizyczny, przeł. E. Wende, Warszawa 1987.

27 G. Marcel, Być i mieć, przeł. P. Lubicz, Warszawa 1962.

28 G. Marcel, Dziennik..., s. 128 n.

${ }^{29}$ Ibidem, s. 131. 
Wspótczesnośćc ${ }^{30}$ (1928), w której omawiał doświadczenie siebie, a także spotkanie z „Innym”. Zauważał, że istotą człowieczeństwa jest to, że człowiek ,nazywa siebie »Ja«"31. Każde „Ja” rozwija się w jakimś systemie myślowym, rozszerza siebie i swój egoizm. Grisebach, stawiając pytanie o zło, ale również o dobro, koncentrował się na „moim” panowaniu nad „Innym”. Zwracał on uwagę, że zawsze towarzyszy nam żądza panowania, czy to nad jednostkami, czy nad narodami. Dopiero w konfrontacji z „drugim”, który stawia „mi” opór, pojawia się zło czy raczej złośliwa natura człowieka. Niemiecki filozof dostrzegał różnicę między przedmiotowością naukową a spotkaniem drugiego człowieka. W przestrzeni relacji z „Ja” i „Ty”, która jest nierówna, trudno kierować się poznaniem, łatwiej zaś rzeczywistością etyczną. W trakcie analizy doświadczenia etycznego pojawiło się dość istotne stwierdzenie Grisebacha, że w prawdziwej wspólnocie żadna ze stron nie może odrzucać prawa innych do wyrażania swoich sądów, do wyłączności ich opinii ${ }^{32}$. W tym sensie ukazywał on społeczność na gruncie etycznym jako spotkanie różnych stron, posiadających równe zasady i poglądy. Opisywał doświadczenie relacji między jednostkami, ale również między narodami czy państwami. Filozofia ta wykracza poza system i poza naukę. Już na wczesnym etapie kształtowania się tej koncepcji widoczne było, że dostrzegała ona wynikające z egocentryzmu i myślenia opartego na tym, co techniczne, zagrożenie dla Europy.

Filozofia dialogu sięgała także, jak w przypadku Rosenzweiga, po myśl Hegla, lecz skupiała się na jej postulacie skoncentrowania się na „Innym” przez pryzmat systemu ${ }^{33}$. Rosenzweig dostrzegał „Innego” w epifanii jego twarzy, której nie można uprzedmiotowić, lecz jedynie pozwolić jej ukazać się, objawić. W tym kontekście pojawia się pytanie o tożsamość i bycie dla „Innego”, stawiane w odniesieniu do religii i etyki.

Dla Bubera tożsamość ugruntowana jest na relacji dialogicznej. Dostrzegał on także relację znajdującą się w strukturze „My”. Odpowiedzią na pytanie o tożsamość jest doświadczenie spotkania. Urodzony w Wiedniu żydowski myśliciel w książce Ja $i$ Ty analizował między innymi problem „My”, a także napięcia między społeczeństwem i państwem, rzutujące na kształt relacji wewnętrznych i zewnętrznych. Relacja dialogiczna wskazuje na niebezpieczeństwo budowania systemu wykluczającego innych i przedstawia propozycję nierozdzielnej pary „Ja-Ty”. Można także i w tym sensie przedstawić stosunek między opartą na wielokulturowości i przyswajaniu sobie różnych tradycji oraz kultur tożsamością europejską a państwami narodowymi, cechującymi się skrajnym nacjonalizmem.

${ }^{30}$ E. Grisebach próbował przedstawić granice między tym, co wewnętrze, i tym, co zewnętrzne. Ukazywał on problem także w odniesieniu do mitu, państwa czy kultury. Zob. idem, Gegenwart. Eine Kritische Ethik, Würzburg 2005, s. 79, https://books.google.pl/books?id=Y-Q_CJYIflU $\mathrm{C} \&$ printsec $=$ copyright\&redir_esc $=\mathrm{y} \# \mathrm{v}=$ onepage $\& \mathrm{q} \& \mathrm{f}=$ false $($ dostęp: 29.08.2020).

31 E. Grisebach, Doświadczenie i spotkanie, [w:] Filozofia dialogu, s. 112.

32 Ibidem, s. 117.

33 F. Rosenzweig, op. cit., s. 56. 
Wymienieni dialogicy nie tylko odnosili się do myśli Hegla i jego koncepcji dziejowości, analogicznie jak do przedstawicieli idealizmu niemieckiego, lecz ukazywali je na gruncie relacji jednostek, które zachowują swoją a u to n o mię. W tych relacjach doszukiwali się źródła kultury europejskiej, dla której podstawą jest przeżycie religijne i etyczne. W czasie walki o uznanie i dominację dostrzegają moc dialogu. To doświadczenie dialogiczne wykracza poza ramy jednej nacji, choć można by przypuszczać, że ze względu na czynne zaangażowanie Bubera w powstanie państwa Izrael, będzie on zainteresowany podkreśleniem znaczenia jednego narodu.

W przeciwieństwie do politycznej tendencji koncentrowania się na tym, co ogólne, na narodzie, przedstawiciele wczesnej filozofii dialogu odkryli u Hegla coś znacznie ważniejszego niż tylko dialektykę. Zauważyli, że wszelka zbiorowość musi być osadzona głęboko na etyce, w której nie chodzi o czerpanie korzyści czy dominacji nad innym, jak pokazał to Gellner w pierwszej fazie badań nad nacjonalizmem i jego definicją ${ }^{34}$, lecz o otwartość na drugiego, „Innego”.

Problemem filozofii dialogu w kontekście pojęcia tożsamości zajmował się Emmanuel Levinas. Kwestia ta na szerszą skalę będzie podejmowana już po II wojnie światowej, po doświadczeniach Holocaustu i upadku kultury Zachodu opartej na niszczeniu tego, co inne. Levinas, podążając za Jeanem Wahlem i odwołując się do krytyki Hegla, buduje filozofię, której podstawowym elementem jest „Inny” i bycie dla niego. To dzięki „Innemu” uzyskujemy swoją tożsamość, bo to on wybiera nas spośród innych. Doświadczenie twarzy „Innego” sprawia, że nasza pierwsza skłonność do zapanowania nad nim przekształca się $\mathrm{w}$ „bycie dla innego". Według francuskiego filozofa kluczowym elementem jest wołanie innego człowieka, który kwestionuje naszą wolność, ale pobudza przez to chęć „bycia dla innego".

Dla Levinasa bardzo ważnym pojęciem była otwartość na „Innego”, wymknięcie się spod panowania tego, co totalizuje, wiąże w całość, totalność. Istotnym elementem jest tu określenie totalności, które wyrasta $\mathrm{z}$ dotychczasowego pojęcia „Ja”, które odrzucając różnorodność, totalizuje. Francuz nie używał słowa „totalitaryzm”, ale „totalizacja”. Nie wspominał o systemie politycznym, lecz o myśleniu odrzucającym „Innego”, które prowadzi do upadku kultury europejskiej. Totalizacja ta jest wynikiem błędnego rozumienia tożsamości i może prowadzić do mechanicznego, technicznego pojmowania samego siebie.

\subsection{Tożsamość i totalność}

W książce Catość i nieskończoność Levinas skoncentrował się na problemie tożsamości, ukazując ją na gruncie relacji tożsamego i tego, co inne. Tożsamy wykracza poza siebie, by być sobą. Inspiracją filozofii Francuza są z jednej strony

34 E. Gellner, op. cit., s. 10. 
Buber czy Rosenzweig, z drugiej zaś Husserl i Heidegger, ale także Henri Bergson czy Durkheim, do którego odnoszą się również badacze próbujący wytłumaczyć zjawisko dwudziestopierwszowiecznego nacjonalizmu (współczesne pojęcia narodu przez pryzmat podziału pracy). Filozofia dialogu, mająca swe źródła w tradycji judaistycznej, dostrzegła problem braku symetryczności w relacjach między ludźmi. Nurt ten pokazywał źródłowe doświadczenie relacji międzyludzkich przez pryzmat spotkania i dialogu, w którym człowiek odkrywa swoją tożsamość. Levinas dokonał nawet przekładu Medytacji kartezjańskich Husserla na język francuski, natomiast do Heideggera nieustannie się odnosił, ukazując problem współczesnej filozofii.

Oprócz zagadnień filozoficznych na myśl Levinasa wpływ wywarły także wydarzenia związane z drugą wojną światową. Jego pytanie o tożsamość i o „Innego”, o mowę dialogiczną odsłania tragizm kultury europejskiej, której głównym problemem staje się pogłębiający się subiektywizm. Francuski myśliciel po doświadczeniu Holocaustu krytykuje hegemoniczną naturę ,Ja”, ograniczającą różnorodność do kręgu własnej tożsamości. Sięga w tym celu do twórczości Durkheima.

Ten bowiem, jak twierdzi Levinas, ukazywał odniesienie „Ja” do „Innego” „tylko poprzez Społeczeństwo, które nie jest po prostu wielością jednostek lub przedmiotów. Ja odnoszę się do Innego, które nie jest zwykłą częścią Całości ani uszczegółowieniem pojęcia. Docierać do Innego przez to, co społeczne, znaczy docierać do niego przez to, co religijne" 35 . Religia u Durkheima nie ma charakteru obiektywnego, lecz jednak z czasem sprowadzona zostaje do zbiorowych przedstawień, co niszczy właściwe doświadczenie transcendencji. Buber i Marcel zauważyli, że nie sposób sprowadzić relacji z „Innym” do relacji z przedmiotem, czyli do obiektywizacji ${ }^{36}$. „Inny” jest bowiem podmiotem, którego nie sposób zamknąć w ramach własnej świadomości czy w procesie obiektywizacji.

Autor Całości i nieskończoności dostrzegał specyfikę relacji z „Innym”. Wejście $\mathrm{w}$ relację z nim, uznanie go oznacza otwarcie, które jest darem. Ja, obdarowując „Innego”, tworzę z nim wspólnotę. Jest to możliwe dzięki językowi, mowie, która nie tyle obiektywizuje, co tworzy wspólną przestrzeń dla spotkania.

Uznać Innego znaczy więc dotrzeć do niego przez świat rzeczy, które posiadam, ale równocześnie, dając, stworzyć poprzez dar wspólnotę i powszechność. Język jest powszechny dlatego, że stanowi przejście od jednostkowości do ogólności, przejście, w którym moje rzeczy ofiarowuję Innemu. Mówić to czynić świat wspólnym, tworzyć wspólne miejsca. Język nie odnosi się do ogólności pojęć, ale rzuca podstawy wspólnego posiadania ${ }^{37}$.

Pojęcie posiadania, które jest obecne także w filozofii Marcela, umożliwiając osąd, bazuje na wspólnym bycie, wspólnocie.

35 E. Levinas, Całość i nieskończoność, przeł. M. Kowalska, Warszawa 1998, s. 65.

36 Ibidem.

37 Ibidem, s. 76. 
W innym miejscu Levinas, próbując przedstawić słabość zachodniego myślenia, stwierdził: „Ja może co prawda obrać inną drogę, by się usprawiedliwić: może próbować ująć się $\mathrm{w}$ ramach całości. Wydaje się, że właśnie w taki sposób próbowano usprawiedliwić wolność w filozofii, która od Spinozy po Hegla utożsamiała wolność z rozumem, wbrew Kartezjuszowi odbierając prawdzie charakter wolnego dzieła, by umieścić ją w łonie bezosobowego rozumu, gdzie zanika opozycja między Ja i Nie-Ja. Wolność nie jest tu zachowana, ale sprowadzona do refleksji ogólnego porządku, który trwa i usprawiedliwia się sam"38. Właśnie w tym sensie, koncentrując się na bezosobowym rozumie, podmiot niweluje różnicę między „Ja” i „Nie-Ja”, strukturę, o której wspominają między innymi Fichte czy Schelling. Levinas dostrzega w tym utożsamieniu wolności z rozumem niebezpieczeństwo przekształcenia się w totalne myślen ie. Słowo totalne oznacza niszczenie różnorodności. To, co odrębne, odmienne, inne staje się częścią całości jednej myśli. Mimo istotnej różnicy między antropologią a politologią wydaje się, że niebezpieczeństwo totalnego myślenia jest dla nich bardzo podobne. Zachowana $\mathrm{w}$ wiekach wcześniejszych różnorodność w obrębie narodu przeobraża się w jedną ideę, która niszczy zróżnicowanie etniczne, językowe, kulturowe, religijne. Jak stwierdził Kant, to ludzki rozum odpowiedzialny jest za ujmowanie różnorodności istniejącej w świecie w szereg przyczynowo-skutkowy.

Levinas, by przeciwstawić się totalnemu myśleniu, koncentrował się na separacji, oddzieleniu tożsamego od „Innego”. Przestrzeń wspólnoty buduje dopiero mowa, która oparta jest na darze i wystawieniu się na zranienie, jak twierdzi francuski intelektualista. Nie oznacza to, że odrzuca ona pytanie o tożsamość, lecz że ugruntowuje ją na bliskości z „Innym”. Dopiero wybranie nas przez „Innego", nasz dar siebie sprawia, że jesteśmy dla niego, to znaczy odnajdujemy siebie w byciu dla „Innego”. W mojej pracy doktorskiej, zatytułowanej HeideggerLevinas. Spór o transcendencje prawdy, określiłem to przeniesienie mianem kat allo ${ }^{39}$, bycia ,dla” i „,z” „Innym”, w odróżnieniu od kat auto, tożsamości wychodzącej i krążącej wokół siebie.

W przywoływanej już tutaj pracy Inaczej niż być lub ponad istota Levinas rozwinął poruszany już wcześniej problem tożsamości, dostrzegając ją w odpowiedzialności za „Innego”, która konstytuuje się w mowie. Właśnie w niej możliwe jest doświadczenie drugiego, którego nie obejmujemy poprzez obiektywizację, ujęcie go poprzez wiedzę, lecz poprzez wycofywanie się z siebie. Dopiero w tym „prześwicie” otwieramy się na „Innego”, stając się jego substytutem. Właśnie w ten sposób ukazuje się odpowiedzialność, która nie niweluje różnic, lecz na ich podstawie pozwala spotkać się ,Ja” i „Innemu”.

Filozofia dialogu walczy z subiektywizmem, występującym w kulturze europejskiej od czasów Kartezjusza. Nacjonalizm w różnych swoich początkowych

38 Ibidem, s. 90.

39 M. Rebes, Heidegger-Levinas. Spór o transcendencję prawdy, Kraków 2005, s. 227. 
fazach charakteryzował przekształcaniem się tożsamości indywiduum w tożsamość wspólnotową. Jednak odznaczał się on subiektywizmem już nie tyle ze strony osoby, co zbioru jednostek, które tworzą naród. W tym sensie filozofia dialogu zwraca się przeciwko establishmentowi. W tym celu posługuje się ona nie językiem racjonalnym, charakteryzującym się pewnym uporządkowaniem, lecz językiem religii rozumianym jako szczególnego rodzaju więź, która nie pozwala na proste przeobrażenie „Innego” w część mojego „ego”. Dokonuje się to na gruncie woli bycia dla Innego.

Dla Levinasa istotną rolę odgrywała nie pierwotna wolność, lecz odpowiedzialność za „Innego" ${ }^{40}$. Filozof doszukiwał się odpowiedzialności za wszystko, także za odpowiedzialność „Innych”41. Ta relacja z „Innym” ma charakter bezinteresowny, porzucana jest w niej jakakolwiek przemoc. Według francuskiego myśliciela wszelka odpowiedzialność jest zobowiązaniem, wypływającym z samego zapytania nas przez „Innego”, czy możemy mu pomóc. Ma ona zatem wydźwięk etyczny, nawet gdy dotyczy spraw społecznych, relacji w społeczeństwie.

W Trudnej wolności Levinas, analizując fragment Biblii, przywołał historię obozu z czasów II wojny światowej, noszącego numer 1492, który nawiązywał do roku wypędzenia Żydów z Hiszpanii za panowania Ferdynanda II Katolickiego. Opowiadając o nieludzkim traktowaniu obozowych więźniów, filozof przedstawił przybłąkanego psa, dla którego wszyscy oni byli ludźmi. Pies Ulissesa i pies ${ }^{42}$, który zjawił się w obozie, są do siebie podobni, ale i różni. Pierwszy z nich witał pana, który wrócił do ojczyzny, Itaki, zaś drugi cieszył się z powrotu ludzi pochodzących z ,nigdzie”. Levinas rozważał problem moralności i przemocy — nie jest ona, jak stwierdził, tylko barbarzyństwem czy egoizmem, lecz jest wynikiem pochopności chęci przyśpieszenia zdarzeń ${ }^{43}$. To przyśpieszenie, przerwanie miałoby pozwolić dotrzeć do samego siebie. Francuski filozof stwierdził, że jest ona efektem braku cierpliwości. Prawdziwa rewolucja jest skutkiem wielkiej litości. Ta pochopność, chęć szybkiej syntezy prowadzi do odrzucenia inności i w konsekwencji do makabrycznej wojny. Przemoc i pochopność, brak cierpliwości i oczekiwanie szybkiego osiągnięcia celu pchają ludzkość do cierpienia innych, do pozbawienia ich odrębności. Ten problem wynika z przyjęcia koncepcji myślenia opartego na zmierzaniu do jednorodności, która leży u podstawy istnienia państw narodowych. Oczywiście z czasem konfrontacja własnej tożsamości narodowej przeszła zmiany i stała się asumptem do szukania płaszczyzny porozumienia między różnymi państwami. Jednak polityka domagała się pewnego rodzaju konfrontacji, która w sensie doświadczenia etycznego jest nie do zaakceptowania.

40 E. Levinas, Etyka i nieskończony. Rozmowy z Philippe'em Nemo, przeł. B Opolska-Kokoszko, Kraków 1991, s. 54.

${ }^{41}$ Ibidem, s. 56.

42 E. Levinas, Trudna wolność. Eseje o judaizmie, przeł. A. Kuryś, Gdynia 1991, s. 162.

43 Ibidem, s. 164. 
Czy filozofia dialogu dostrzega problem nacjonalizmu? W dedykacji do Inaczej niż być lub ponad istota Levinas napisał: „Pamięci najbliższych spośród sześciu milionów zamordowanych przez narodowych socjalistów, obok milionów istot ludzkich różnych wyznań i narodowości, będących ofiarami tej samej nienawiści do drugiego człowieka, tego samego antysemityzmu"44. Filozof nie deprecjonuje pojęcia narodu, ale poważnie zastanawia się nad nacjonalizmem, którego podstawą jest walka o uznanie, o prymat, która używa w tym celu niewłaściwych środków, takich jak nienawiść czy źle rozumiane współzawodnictwo. Filozofia dialogu chce temu zaradzić, odwołując się do doświadczenia innego człowieka.

W odróżnieniu od nacjonalizmu filozofia dialogu czyni „Innego” elementem odpowiadającym na pytanie o tożsamość człowieka. Odrzuca też celowość, finalność. Nacjonalizm definiował tożsamość w kontekście przynależności politycznej, a także społecznej (tożsamość jako łacińskie idem, angielskie same czy niemieckie selbig, gleich ${ }^{45}$ ). Kluczową rolę w określaniu, wspieraniu tożsamości odgrywał „Inny”, ale jako punkt odniesienia, a właściwie oddzielenia, odseparowania się od niego. Filozofia dialogu krytykuje dialektykę, ponieważ dla niej najważniejsze jest spotkanie indywiduum z perspektywy etycznej, „Inny” jest nieodzownym elementem tożsamości.

\section{Nacjonalizm i uniwersalne przesłanie filozofii dialogu}

Powróćmy do teorii nacjonalizmu, by zwrócić uwagę na jego konfrontacyjny charakter i kluczową wartość, czyli zasadę walki.

D my tro D o n c ow w przedmowie do swojej książki Nacjonalizm ${ }^{46}$ zauważył, że dotychczas także w odniesieniu do nacjonalizmu odwoływano się do różnych wartości, które obecnie zanikają, lecz pozostała jedna z nich, czyli z a s a d a w a $1 \mathrm{k}$ i. Wcześniej traktowana była przez pryzmat rozumu, który wyznaczał pewne prawa, zaś aktualnie na pierwszy plan wysuwa się wo la. Doncow stwierdził na przykładzie Ukrainy, że tym samym procesom podlega nacjonalizm. Kluczem do niego są walka i wola. Pogłębiając problem, dostrzec możemy zarówno wspomnianą wcześniej kwestię walki, rzekomo dostrzeganą u Hegla w jego dialektyce, jak i irracjonalizm Schopenhauera czy Nietzschego. Kultura europejska przyzwyczaiła się do dialektyki i uprawiania polityki na gruncie bliżej nieokreślonej woli.

${ }^{44}$ E. Levinas, Inaczej niż być lub ponad istota, przeł. P. Mrówczyński, Warszawa 2000, s. 5.

45 Paul Ricoeur w swoim wykładzie zatytułowanym Tożsamość osobowości rozróżnia dwa typy tożsamości: ipse i idem. Tożsamość idem jest „tożsamością tego, co jednostkowe”, natomiast ipse „tożsamością siebie samego”. Pierwszy typ opiera się na jednakowości, drugi na byciu sobą (P. Ricoeur, Filozofia osoby, przeł. M. Frankiewicz, Kraków 1992, s. 33). W przypadku skrajnie pojmowanego nacjonalizmu tożsamość idem zdominowała znaczenie ipse.

46 D. Doncow, Nacjonalizm, przeł. W. Poliszczuk, Kraków 2008, s. 29. 
Podobne spostrzeżenia co Doncow miał Levinas, który w Trudnej wolności w kontekście zmian, jakie dokonują się wśród Żydów, zauważył, że ci „radośnie zaakceptowali wszelkie nacjonalizmy, a także kłótnie, wszelkie namiętności. Izrael nie stał się gorszy od otaczającego świata, cokolwiek by mówili antysemici ale przestał być lepszy. Być najsilniejszym — do tego sprowadzały się dążenia»47 Dalej francuski filozof pisał, że początkowo Żydzi przyjęli to, co przyniósł otaczający świat, a potem sprzeciwili się temu. W ten sposób odrzucili język, w którym głęboko tkwili. „Będąc jedynie czymś w sferze woli, by samego siebie zro-

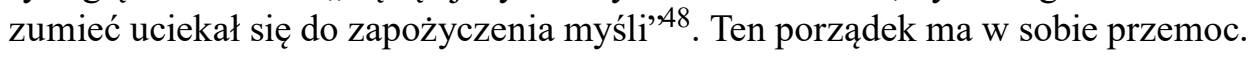
Aby ją pokonać, należy powiązać rozum, język i moralność. Dialogicy domagają się przywrócenia różnorodności, odwołując się do doświadczenia religijnego, do relacji, która wciąż pozostawia różnice.

Właśnie etyczne doświadczenie różni nacjonalizm od filozofii dialogu. Przedstawia się ono zamiast dialektyki, jak pokazaliśmy wcześniej, w dialogu, czyli mowie, która konstytuuje się w relacji między ludźmi.

\subsection{Filozofia dialogu a narodowy socjalizm}

Jak mogliśmy zauważyć, filozofia dialogu inaczej interpretuje Hegla i jego pojęcia predestynacji oraz dziejowości. Niemiecki filozof, piewca wolności, w swojej Fenomenologii ducha zauważył, że proces poznania polega na przyswojeniu sobie tego, co inne ${ }^{49}$. Filozofia dialogu to, co inne, chce jednak pozostawić w źródłowym doświadczeniu poza sferą uporządkowania.

Tak jak na gruncie kultury i polityki w przezwyciężeniu skrajnie nacjonalistycznych tendencji mają pomóc różnego rodzaju instytucje międzynarodowe, które mają stać na straży praworządności, tak filozofia dialogu przeciwstawia się procesowi totalizacji, unifikacji zróżnicowanego świata do własnego „Ja”, wspierając poszukiwanie własnej tożsamości w odniesieniu do relacji z „Innym”. Filozofia dialogu postuluje zniwelowanie wszelkiej wrogości przy zachowaniu istotnych różnic między podmiotami. Szczególnym czasem, w którym zachowanie odrębności wydawało się coraz bardziej potrzebne, były lata trzydzieste XX wieku. Cezurę stanowi okres upowszechniania się idei narodowego socjalizmu. Pojęcie to pojawiało się już wcześniej, pod koniec XIX wieku, lecz dopiero w kolejnym stuleciu stanie się ono doktryną polityczną. Jedną z najważniejszych idei narodowego socjalizmu był nacjonalizm.

Myśl narodowego socjalizmu oparta była, tak jak już wcześniej wspominaliśmy przy omawianiu nacjonalizmu, na filozofii Hegla, Schopenhauera czy Nietzschego. Pozostawiając na uboczu te nurty, możemy skupić się na Johannie Gott-

\footnotetext{
${ }^{47}$ E. Levinas, Trudna wolność..., s. 6.

48 Ibidem.

49 G.W.F. Hegel, op. cit., s. 133 n.
} 
liebie Fichtem, który wiązał ze sobą tożsamość i naród rozumiane przez pryzmat pojęć Volk i Ur-Volk (pranarodu). Poglądy Fichtego, nazywane także volkizmem, dotyczyły ducha, a z czasem zostały utożsamione z przynależnością narodową. $\mathrm{Na}$ gruncie tych pojęć został nakreślony cel i przeznaczenie narodu. Wizja Hegla czy Fichtego daleka była od dwudziestowiecznego rozumienia narodu, ale mimo to stała się pożywką dla późniejszych ideologii. W Podstawach całkowitej teorii wiedzy Fichte stwierdził, że „nie ma Ja bez Ty i Ty bez Ja" ${ }^{50}$. Dostrzegł on konieczność wspólnoty, której owocem jest naród (Nation). Fichte rozumie go jednak w kontekście elementów kulturowych.

Narodowy socjalizm spłycał idee idealizmu niemieckiego, także Schopenhauera czy Nietzschego. Ich myślą przewodnią była tożsamość i idea predestynacji. Filozofia dialogu podejmuje problem tożsamości, która stoi u podstaw wszelkiej identyfikacji społecznej, identyfikacji grupy, subkultury czy kultury narodowej. Jak pokazuje przykład Fichtego, relację „Ja-Ty” można rozumieć na różne sposoby, to jest w kontekście spotkania człowieka z człowiekiem, a także wspólnoty, która buduje. Jakkolwiek by na to nie patrzeć, tym, co wiąże filozofię dialogu i obawę przed przejściem w skrajną postać nacjonalizmu, jest stosunek do „Innego”.

Ten nadaje sensu doświadczeniu tożsamości i nie można go pomijać czy eliminować, lecz należy uwzględniać różnicę istniejącą między mną a „Innym”. Myśl filozofii dialogu, gdyby inspirowała idee skrajnego nacjonalizmu, mogłaby utracić swoją atrakcyjność dla ludzi, którzy poszukują w niej wzmocnionego przekazu tożsamości narodowej.

\subsection{Tożsamość i „Inny”}

Jak wykazaliśmy powyżej, filozofia dialogu opiera się na pytaniu Fichtego i Hegla o tożsamość, odrzuca jednak przy tym dialektykę na rzecz coincidentia opossitorum. Dostrzega, że dzięki „Innemu” możemy dopiero odnaleźć siebie. Hegel w Fenomenologii ducha koncentrował się na poznawaniu przez człowieka siebie i świata i w tym kontekście odkrył, że proces poznawczy, ale także i wolność człowieka, polegają na przyswajaniu sobie tego, co od niego inne. Filozofia dialogu przestrzega przed niebezpieczeństwem budowania świata, w którym inność jest redukowana. Nawet w średniowiecznych narodach istniały obok siebie różne wspólnoty, cechy, ale w nowożytności państwa narodowe domagały się jednorodności. Na poziomie myślenia pojawił się totalizm, rozumowanie całościowe, towarzyszące także narodowemu socjalizmowi, który miał łączyć prawą i lewą stronę sceny politycznej, lecz de facto niszczył różnorodność. Filozofia dialogu, mimo że nie zajmuje się problemem nacjonalizmu czy państw narodowych, a przynajmniej nie stanowi to jej istoty, jest jednak wyczulona na problem "Innego" i struktury relacji.

50 J.G. Fichte, Teoria wiedzy. Wybór pism, t. 1, przeł. M. J. Siemek, Warszawa 1996, s. 202. 
Nurt ten w procesie dochodzenia do tożsamości dostrzega niebezpieczeństwo totalizacji. Nie można utożsamiać tego pojęcia z totalitaryzmem, który jest systemem politycznym i jednak bazuje na totalności, to znaczy na całościowym pojmowaniu świata „Ja”, innych ludzi, Boga i zewnętrznej rzeczywistości. Ten pluralizm rzeczy leżał u podstaw narodów w epoce średniowiecza czy nawet antyku, lecz to nowożytna nauka zaczęła ujmować w całość różnorodność świata, również w sferze polityki. Ta totalizacja to odrzucenie różnicy, która znajduje się między nami. Totalność to eliminacja dzielącej nas różnicy na rzecz porządkującego świat ludzkiego „ego”. Filozofowie dialogu, którzy początkowo walczą z subiektywizacją życia, w okresie dominacji narodowego socjalizmu przeżywają traumę, gdy obserwują eksterminację ludzkości. Dlatego u Levinasa totalność, tożsamość jako kat auto przekształca się w ,jeden za drugiego".

Czy można nacjonalizm budować na idei dialogu, współpracy? Pytanie wydaje się retoryczne. Nie tylko może, ale powinien on być budowany na współpracy międzynarodowej, poszanowaniu szeroko rozumianego pojęcia „Innego”. W innym przypadku nacjonalizm niszczy esencję życia społecznego. Kluczową kwestią jest jednak zrozumienie, że dla tożsamości narodowej ważniejsze jest zachowanie wszelkiej odrębności, także własnej kulturowej identyfikacji, niż konfrontacja.

\section{Podsumowanie}

Reasumując, $w$ niniejszym artykule próbowałem przedstawić problem nacjonalizmu przez pryzmat takich cech jak symetryczność relacji czy problem p r ze m o c y. Nie było moim zadaniem znalezienie wspólnej dla wszystkich nacjonalizmów definicji, lecz wyróżnienie niektórych skrajnych, ale jednak stosunkowo najbardziej reprezentatywnych, jego odmian. Widać to wyraźnie w kontekście pytania o tożsamość. Nie chodzi też o to, aby nacjonalizm klasyfikować jako dobry bądź zły. Jednak pewne elementy i cechy mogą budzić zastrzeżenia i słuszne obawy. Nacjonalizm z jednej strony bazuje na uniwersalizmie, $z$ drugiej zaś doszukuje się wyjątkowości, wyjątkowego miejsca dla swojego narodu. Stoi w jawnej sprzeczności wobec uniwersalnych wartości, które są dla wszystkich takie same. Spór o tożsamość z perspektywy filozofii dialogu dotyka ważnego zagadnienia, jakim jest w tym aspekcie znaczenie „Innego”. Źle zrozumiana filozofia Kanta, Hegla czy Nietschego może prowadzić do wniosków, że są oni prekursorami nacjonalizmu, w tym narodowego socjalizmu. Jest to jednak wielkie nieporozumienie. Filozofia dialogu krytycznie ocenia tych myślicieli, ale dali oni jej asumpt do przemyśleń nad istotą i źródłowym pytaniem filozofii.

Omawiany prąd myślowy pokazuje, że indywidualne doświadczenie może mieć charakter uniwersalny, nie wykluczając przy tym innych. To pomaga dostrzec konieczną równowagę między tożsamościami europejską i narodową, które potrzebują siebie nawzajem. Przedstawiciele filozofii dialogu spotykali się z na- 
cjonalizmem szczególnie w jego dwóch odsłonach — po pierwsze, gdy mowa jest o utworzeniu państwa Izrael, po drugie, w kontekście dramatu wojen światowych. Nurt ten nie jest zwrócony przeciwko państwom narodowym, lecz przeciwko nacjonalizmowi, który niszczy kulturowe, religijne, a także państwowe korzenie. Tożsamość narodowa jest bardzo ważnym elementem natury człowieka, lecz musi być ugruntowana na symetryczności relacji międzyludzkich — to podstawa wszelkiego bezpieczeństwa.

\section{Bibliografia}

\section{Literatura}

Baran B., Przedmowa, [w:] Filozofia dialogu, oprac. B. Baran, Kraków 1991.

Buber M., Autobiographische Fragmente, [w:] Philosophie of Martin Buber, Evanston 1963.

Buber M., Ja i Ty. Wybór pism filozoficznych, przeł. J. Doktór, Warszawa 1992.

Buber M., Problem człowieka, przeł. R. Reszke, Warszawa 1993.

Casper B., Wstęp, [w:] F. Ebner, Stowo i realności duchowe, Warszawa 2006.

Cohen H., Religion der Vernunft aus den Quellen des Judentums. Eine judischen Religionsphilosophie, Wiesbaden 2008, https://pdfs.semanticscholar.org/4dec/0268d80728a36005bc73c10f $5 \mathrm{dblc2e00a0e.pdf.}$

Doncow D., Nacjonalizm, przeł. W. Poliszczuk, Kraków 2008.

Durkheim E., O podziale pracy społecznej, przeł. K. Wakar, Warszawa 2012.

Ebner F., Fragmenty pneumonologiczne, [w:] Filozofia dialogu, oprac. B. Baran, Kraków 1991.

Fichte J.G., Teoria wiedzy, t. 1, przeł. M.J. Siemek, Warszawa 1996.

Filozofia dialogu, oprac. B. Baran, Kraków 1991.

Gellner E., Narody i nacjonalizm, przeł. T. Hołówka, Warszawa 1991.

Grisebach E., Doświadczenie i spotkanie, [w:] Filozofia dialogu, oprac. B. Baran, Kraków 1991.

Grisebach E., Gegenwart. Eine Kritische Ethik, Würzburg 2005, https://books.google.pl/books? $\mathrm{id}=\mathrm{Y}-\mathrm{Q} \_$CJYIflUC\&printsec $=$copyright\&redir_esc $=\mathrm{y} \# \mathrm{v}=$ onepage $\& \mathrm{q} \& \mathrm{f}=$ false.

Hegel G.W.F., Fenomenologia ducha, oprac. Ś.F. Nowicki, Warszawa 2002.

Kant I., O wiecznym pokoju. Zarys filozoficzny, przeł. F. Przybylak, Wrocław 1992.

Kant I., Krytyka czystego rozumu, t. 2, przeł. R. Ingarden, Kraków 1957.

Kant I., Krytyka praktycznego rozumu, przeł. J. Gałecki, Warszawa 2004.

Levinas E., Całość i nieskończoność. Esej o zewnętrzności, przeł. M. Kowalska, Warszawa 1998.

Levinas E., Etyka i nieskończoność. Rozmowy z Philippe'em Nemo, przeł. B Opolska-Kokoszko, Kraków 1991.

Levinas, E., Inaczej niż być lub ponad istota, przeł. P. Mrówczyński, Warszawa 2000.

Levinas E., Trudna wolność. Esej o judaizmie, przeł. A. Kuryś, Gdynia 1991.

Marcel G., Być i mieć, przeł. P. Lubicz, Warszawa 1962.

Marcel G., Dziennik metafizyczny, przeł. E. Wende, Warszawa 1987.

Nietzsche F., O prawdzie i klamstwie w pozamoralnym sensie, [w:] Pisma pozostałe 1862-1875, przeł. B. Baran, Kraków 1993.

Nietzsche F., Wola mocy, przeł. S. Frycz i K. Drzewiecki, Kraków 2006.

Rebes M., Heidegger-Levinas. Spór o transcendencję prawdy, Kraków 2005.

Rosenstock-Huessy E., Angewandte Seelenkunde. Eine Programmatische Übersetzung, Darmstadt 1924. 
Rosenstock-Huessy E., Gramatyka duszy, przeł. T. Gadacz, [w:] Filozofia dialogu, oprac. B. Baran, Kraków 1991.

Rosenzweig F., Gwiazda Zbawienia, przeł. T. Gadacz, Kraków 1998.

Scheler M., Resentyment a moralność, przeł. J. Garewicz, Warszawa 1997.

Schopenhauer A., Świat jako wola i przedstawienie, t. 1, przeł. J. Garewicz, Warszawa 1994.

Walicki A., Nacjonalizm i społeczeństwo obywatelskie w teorii Ernesta Gellnera, [w:] Idee a urzadzanie świata społecznego. Księga jubileuszowa dla Jerzego Szackiego, red. E. Nowicka, M. Chałubiński, Warszawa 1999. 